\title{
Article \\ Sir4 Deficiency Reverses Cell Senescence by Sub-Telomere Recombination
}

\author{
Jun Liu ${ }^{1, * \mathbb{D}}$, Xiaojing Hong ${ }^{1}$, Lihui Wang ${ }^{1}$, Chao-Ya Liang ${ }^{1}$ and Jun-Ping Liu ${ }^{1,2,3, *(\mathbb{D})}$ \\ 1 Institute of Ageing Research, School of Medicine, Hangzhou Normal University, Hangzhou 311121, China; \\ xiaojing.hong@hznu.edu.cn (X.H.); wanglihui100@163.com (L.W.); liangchaoya1992@163.com (C.-Y.L.) \\ 2 Department of Immunology, Faculty of Medicine, Monash University, Prahran, VIC 3181, Australia \\ 3 Hudson Institute of Medical Research, Clayton, VIC 3168, Australia \\ * Correspondence: junliu262@hznu.edu.cn (J.L.); jun-ping.liu@monash.edu (J.-P.L.)
}

Citation: Liu, J.; Hong, X.; Wang, L.; Liang, C.-Y.; Liu, J.-P. Sir4 Deficiency Reverses Cell Senescence by Sub-Telomere Recombination. Cells 2021, 10, 778. https://doi.org/ 10.3390/cells10040778

Academic Editor: David Gilley

Received: 5 March 2021

Accepted: 30 March 2021

Published: 1 April 2021

Publisher's Note: MDPI stays neutral with regard to jurisdictional claims in published maps and institutional affiliations.

Copyright: (c) 2021 by the authors. Licensee MDPI, Basel, Switzerland. This article is an open access article distributed under the terms and conditions of the Creative Commons Attribution (CC BY) license (https:// creativecommons.org/licenses/by/ $4.0 /)$.

\begin{abstract}
Telomere shortening results in cellular senescence and the regulatory mechanisms remain unclear. Here, we report that the sub-telomere regions facilitate telomere lengthening by homologous recombination, thereby attenuating senescence in yeast Saccharomyces cerevisiae. The telomere protein complex Sir3/4 represses, whereas Rif1 promotes, the sub-telomere $Y^{\prime}$ element recombination. Genetic disruption of SIR4 increases $\mathrm{Y}^{\prime}$ element abundance and rescues telomere-shortening-induced senescence in a Rad51-dependent manner, indicating a sub-telomere regulatory switch in regulating organismal senescence by DNA recombination. Inhibition of the sub-telomere recombination requires Sir4 binding to perinuclear protein Mps3 for telomere perinuclear localization and transcriptional repression of the telomeric repeat-containing RNA TERRA. Furthermore, Sir4 repression of $Y^{\prime}$ element recombination is negatively regulated by Rif1 that mediates senescence-evasion induced by Sir4 deficiency. Thus, our results demonstrate a dual opposing control mechanism of sub-telomeric $\mathrm{Y}^{\prime}$ element recombination by Sir3/4 and Rif1 in the regulation of telomere shortening and cell senescence.
\end{abstract}

Keywords: cell senescence; senescence regulation; sub-telomeres; telomere binding protein; Sir4; Rif1; yeast

\section{Introduction}

Telomeres at the termini of eukaryotic chromosomes regulate genome stability and cell fate. Shortening of telomeres constitutes a mechanism against the proliferative potential of eukaryotes and induces DNA damage response and genome instability [1-5]. Recruitment of telomerase by specific proteins on telomeres rescues telomere shortening [6,7]. In the budding yeast Saccharomyces cerevisiae, telomerase contains the catalytic reverse transcriptase subunit Est2, intrinsic RNA template TLC1, two accessory protein subunits Est1 and Est3 [8-12], and Pop1/6/7 subunits [13]. For recruitment, two telomerase components are recognized specifically, with Est1 bound by the single-stranded telomeric DNA (ssDNA) binding protein Cdc13 in the cell cycle S phase and TLC1 bound by the double-stranded telomeric DNA (dsDNA) binding protein $\mathrm{Ku}$ complex (Yku70/80) in the G1 phase $[6,7,14,15]$. Disruption of Yku80-TLC1 interaction by the $y k u 80-135 i$ allele results in telomere shortening [14], but not as short as that of $y k u 80 \Delta$ cells, suggesting that $Y k u$ has other functions at telomere ends, e.g., restricting the invasive action of ExoI exonuclease to telomere C-strand resection [16,17].

Deprotection of telomeres with telomerase deficiency leads to replicative senescence [18]. Disruption of Cdc13 interaction with Est1 [19], EST1 deletion [20], yku80 mre $11 \Delta$ cells [21], or yku70 $\Delta$ mre $11 \Delta$ cells [22] causes cell senescence. Similar to mammalian alternative lengthening of telomeres (ALT), however, yeast cells escape senescence to form two types of survivors: type I survivor characteristic of highly amplified sub-telomeric $\mathrm{Y}^{\prime}$ elements and type II survivor with heterogeneous telomere $\mathrm{TG}_{1-3}$ sequence recombination [20]. Both types of survivors require Rad52 which generally mediates homologous 
recombination $[20,23]$ including the break-induced replication-mediated telomere elongation [24,25]. In addition, type I survivors require Rad51, Rad54, Rad55, and Rad57 to amplify sub-telomeric $Y^{\prime}$ elements, and make use of the Rad59-mediated Rad52 strand annealing activity to delay the onset of senescence [26].

Telomere lengthening that takes place in the absence of telomerase via DNA homologous recombination has been investigated [20,27-29]. However, which telomere proteins regulate the sub-telomere recombination remains unclear. Sir4, Sir3, Rif1, and Rif2 are recruited to duplex telomeres by interacting with the carboxyl termini of Rap1 [8,9], with Sir4 further recruiting Sir2 and Sir3 to telomeres [30]. Whereas Sir4-Sir2-Sir3 ternary complex participates in chromatin silencing [30] by interacting with not only Rap1 but also Yku80 [31,32], Rif1 and Rif2 inhibit the recruitment of telomerase to telomeres [33,34]. Moreover, in G1 phase, while silencing duplex telomeres, Sir4 binding to Yku80 recruits Yku80-TLC1 telomerase complex to the $3^{\prime}$ G-rich single strand telomeres [6,7], as Yku70/80 bindings to telomerase RNA TLC1 or telomeric DNA are mutually exclusive [35].

Deletion of YKU80 and MRE11 results in a senescence-like phenotype even in the presence of telomerase [22], whose mechanism is not fully understood. The present study aimed to determine how telomere-proteins Sir2, Sir3, Sir4, Rif1, and Rif2 regulate senescence and sub-telomere recombination in the presence of telomerase. We observed that Sir 4 deficiency rescued yku $80 \Delta$ mre11 $\Delta$ cell senescence by significantly increasing subtelomere $Y^{\prime}$ element amplification and telomere lengthening. Consistently, loss of Sir4-Mps3 interaction-mediated telomere perinuclear localization and increase in TERRA transcription contribute to $Y^{\prime}$ element amplification induced by Sir4 deficiency in yku80 $\Delta$ mre $11 \Delta$ cells. We further showed that Rif1 deficiency, or Rif1/2 deficiencies, suppressed yku80 $\Delta$ mre11 $\Delta$ cell senescence by lengthening telomeres and inhibiting $\mathrm{Y}^{\prime}$ element amplification. Thus, our studies demonstrate that in the presence of active telomerase, Sir4 deficiency significantly increases sub-telomere $Y^{\prime}$ element amplification to lengthen telomeres, which is amendable by Rif1 or Rif1/2 deficiencies in diverting cellular senescence in yeast.

\section{Material and Methods}

\subsection{Strains, Oligonucleotides, and Genetic Manipulations}

Saccharomyces cerevisiae and plasmids used in this study are shown in Table S1. Gene knock-out (KO) mutants were constructed as described previously [36,37]. Heterozygous diploid strains with one copy gene targeted were subjected to sporulation and tetrad dissection. Gene KO cassettes were specifically amplified by PCR using highfidelity DNA polymerase in the following plasmids: pFA6a-HIS3MX6 (HIS3MX6), pFA6aKanMX6 (KanMX6), pYM-N15 (N15), or pFA6a-8Glyc-13Myc-HphMX6 (HphMX6). Listed in Table S2 are the PCR combinations of paired primers and corresponding plasmidtemplates for amplification of gene $\mathrm{KO}$ cassettes. Other primers used in this study are listed in Table S3.

\subsection{Sporulation and Micromanipulation}

Diploid strains were subjected to sporulation using a protocol described previously in SGD (http:/ / www-sequence.stanford.edu/group/yeast_deletion_project/spo.html, accessed on 31 March 2021) with modifications. For details, refer to supplemental information.

\subsection{Telomere Length and $Y^{\prime}$ Element Analyses by Southern Blot}

Yeast strains were grown on YPD or selective synthetic medium plates as indicated in a $30{ }^{\circ} \mathrm{C}$ incubator for 3-4 days. Single colonies were successively streaked on fresh YPD or selective synthetic plates every 3-4 days, cells from the plates were collected, washed, and stored at $-80^{\circ} \mathrm{C}$ freezer. Genomic DNA isolation and telomere length measurement were performed by Southern blotting as described previously [38]. 


\subsection{Cell Senescence Analysis}

For cell senescence analysis in yeast liquid cultures, spores with indicated genotypes were inoculated into $500 \mu \mathrm{L}$ fresh YPD liquid medium and incubated overnight to prepare saturated cultures at $30^{\circ} \mathrm{C} 220 \times \mathrm{rpm}$. A calculated quantity of cells for each genotype was diluted into $10 \mathrm{~mL}$ fresh YPD medium to give an initial concentration of $\mathrm{A} 600_{\mathrm{nm}}=0.01$. Cell density $\left(\mathrm{A} 6000_{\mathrm{nm}}\right)$ was measured by a spectrophotometer, calculated and re-diluted into $10 \mathrm{~mL}$ fresh YPD medium approximate every $20 \mathrm{~h}$. Cells of the liquid culture were collected and washed with water for DNA extraction. For cell senescence analysis on YPD plate, different colonies of spores for each genotype were streaked every $48 \mathrm{~h}$ and followed by photographing and re-streaking on fresh plates.

\subsection{Quantitative Analysis of Genomic $Y^{\prime}$ Element Copy Numbers}

$\mathrm{Y}^{\prime}$ element relative copy numbers in genomic DNA was analyzed by real-time quantitative PCR using primers specific to amplify consensus DNA fragment in all the $19 \mathrm{Y}^{\prime}$ elements of 17 telomeres of 13 S.cerevisiae chromosomes [39]. Data are results from 3-5 biological replicates and expressed as averages with S. E. M. indicated by error bars.

\subsection{Statistical Significance Calculation}

Statistical calculation was done by using the two-sided student's t test. The $p$ value considered statistically significant was set to be smaller than 0.05 .

\section{Results}

\subsection{Sir3/4, But Not Sir2, Deficiency Rescues Senescence}

To investigate if Sir2/3/4 play a potential role in the senescence of $y k u 80 \Delta$ mre11 $\Delta$ cells, we constructed diploid strains heterozygous for $y k u 80 \Delta, m r e 11 \Delta, \operatorname{sir} 2 \Delta, \operatorname{sir} 3 \Delta$, and $\operatorname{sir} 4 \Delta$. The strains were sporulated and tetrad dissected, respectively (Figures S1 and S2), yku80 $\Delta$ mre $11 \Delta$ cells grew normally at 1 st streakout, significantly slow displaying senescence phenotype at the 3rd streakout (Figure 1A), consistent with the senescence phenotype

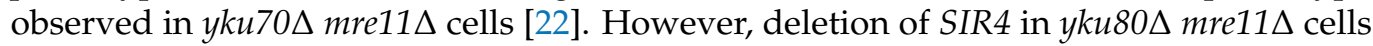
showed comparable growth rates to that of $m r e 11 \Delta$ and mre $11 \Delta$ sir $4 \Delta$ cells (Figure $1 \mathrm{~A}$ ), so

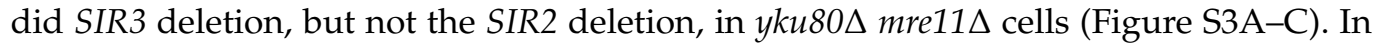
liquid senescence assay, yku80 $\Delta$ mre $11 \Delta$ cells exhibited significantly reduced proliferative rate and subsequently succumbed to senescence at the 3rd passage as compared to $m r e 11 \Delta$ sir $4 \Delta, y k u 80 \Delta$ sir $4 \Delta$, and mre $11 \Delta$ cells (Figure 1B). Sir 4 deficiency in $y k u 80 \Delta$ mre $11 \Delta$ cells prevented senescence leading to cell density comparable to that of mre11 $\Delta$ and mre $11 \Delta$ sir $4 \Delta$ cells (Figure 1B). Consistently, the cell density of $y k u 80 \Delta$ mre $11 \Delta$ sir $4 \Delta$ cells was significantly

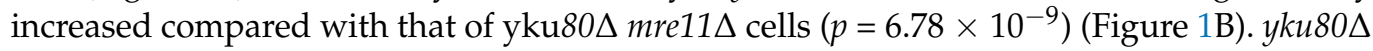
mre $11 \Delta$ and $y k u 80 \Delta$ mre $11 \Delta$ sir $2 \Delta$ cells exhibited slow growth rate to the extent by and large indifferent from that of $y k u 80 \Delta$ mre $11 \Delta$ senescent cells following six successive passages

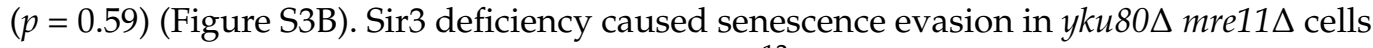
similar to that of Sir4 deficiency $\left(p=8.86 \times 10^{-13}\right)$ (Figure S3B). Together, these results demonstrated that the senescent phenotype induced by the $y k u 80 \Delta$ mre $11 \Delta$ deficiencies is circumvented by the deprivation of Sir3 or Sir4, but not Sir2.

Consistently, subculturing WT, yku80 $\operatorname{mre} 11 \Delta, y k u 80 \Delta$ mre $11 \Delta$ sir $2 \Delta, y k u 80 \Delta$ mre $11 \Delta$ sir $3 \Delta$, yku $80 \Delta$ mre $11 \Delta$ sir $4 \Delta$ cells by proportional dilution and plating onto fresh YPD plates to observe the growth phenotype of single colonies showed that $y k u 80 \Delta$ mre11 $\Delta$ and $y k u 80 \Delta$ mre $11 \Delta$ sir $2 \Delta$ cells were less with a mixture of small and large colonies compared to that of WT cells (Figure S4), but deletion of SIR3 or SIR4 inhibited the senescence of

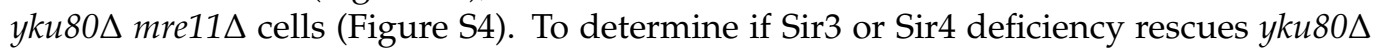
mre11 $\Delta$ cell senescence through the same pathway, we constructed diploid strain that was heterozygous for $y k u 80 \Delta$ mre $11 \Delta \operatorname{sir} 3 \Delta \operatorname{sir} 4 \Delta$ (Figure S5). The results showed that the cell density of $y k u 80 \Delta$ mre $11 \Delta \operatorname{sir} 3 \Delta$ sir $4 \Delta$ cells are indistinguishable to that of $y k u 80 \Delta$ $m r e 11 \Delta \operatorname{sir} 3 \Delta$ and $y k u 80 \Delta$ mre $11 \Delta$ sir $4 \Delta$ cells following six successive passages (Figure S6). 
These data show that Sir3 or Sir4 deficiency rescues $y k u 80 \Delta$ mre11 $\Delta$ cell senescence by the same pathway.

A

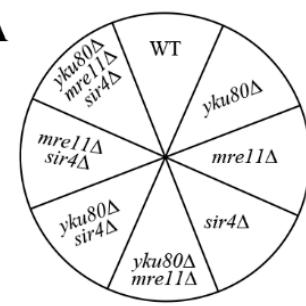

\#3

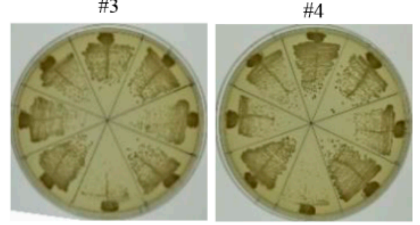

B

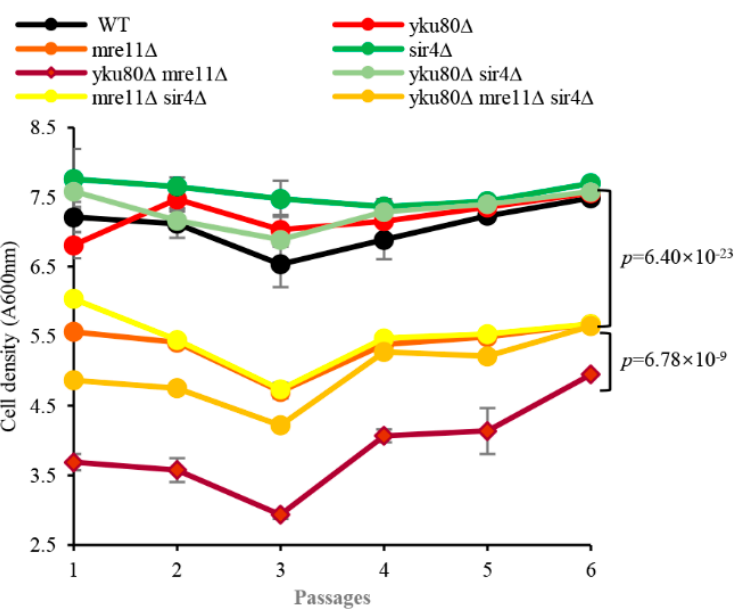

C

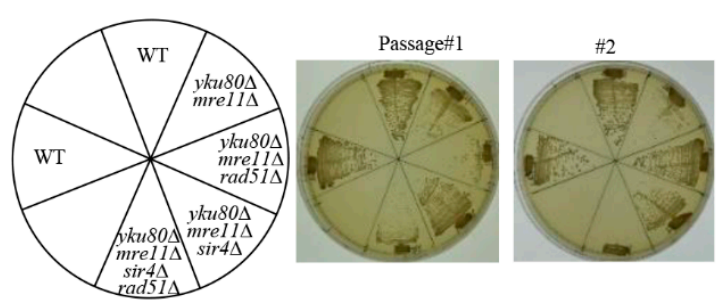

\#3

\#4

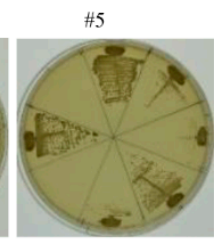

\#6

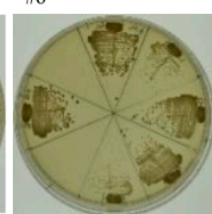

D

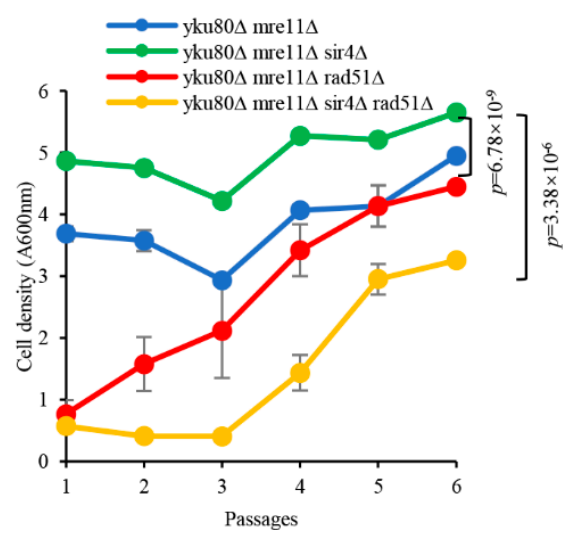

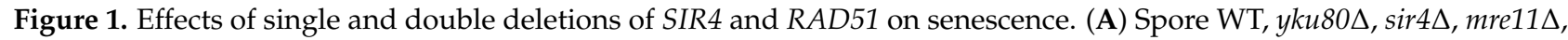
$y k u 80 \Delta \operatorname{sir} 4 \Delta, y k u 80 \Delta$ mre $11 \Delta, m r e 11 \Delta$ sir $4 \Delta$, and $y k u 80 \Delta$ mre11 $\Delta$ sir $4 \Delta$ cells were successively streaked on YPD plates every 2 days for six times. Images of photographed colony growth are from one of typical 5 experiments. (B) Spore cells indicated in (A) were cultured in liquid YPD medium at $30{ }^{\circ} \mathrm{C} 220 \times \mathrm{rpm}$ with initial concentration of $\mathrm{A} 600_{\mathrm{nm}}=0.01$ for around $20 \mathrm{~h}$ and followed by $\mathrm{A} 600 \mathrm{~nm}$ measurement, and re-dilution was made every $20 \mathrm{~h}$. Results are mean \pm SEM $(n=5)$. (C) Spore WT, yku80 $\operatorname{mre} 11 \Delta, y k u 80 \Delta$ mre $11 \Delta$ sir $4 \Delta, y k u 80 \Delta$ mre $11 \Delta$ rad51 $1 \Delta, y k u 80 \Delta$ mre $11 \Delta$ sir $4 \Delta$ rad $51 \Delta$ cells were successively streaked on YPD plates every 2 days for six times. Images of photographed colony growth are from one of typical 5 experiments. (D) Spore cells indicated in (C) were cultured in liquid YPD medium at $30{ }^{\circ} \mathrm{C} 220 \times$ rpm with initial concentration of $\mathrm{A} 600_{\mathrm{nm}}=0.01$ for around $20 \mathrm{~h}$ and followed by $\mathrm{A} 600 \mathrm{~nm}$ measurement, and re-dilution was made every $20 \mathrm{~h}$. Results are mean $\pm \operatorname{SEM}(n=5)$.

\subsection{Rad51 Is Required for Senescence Evasion Induced by Sir4 Deficiency}

We next determined whether Rad52 is required for rescuing senescence by Sir4 deficiency. Diploid strain heterozygous for $y k u 80 \Delta, m r e 11 \Delta$, sir $4 \Delta$, and $\operatorname{rad} 52 \Delta$ was sporulated and tetrad dissected (Figure S7). But $y k u 80 \Delta$ mre $11 \Delta$ rad52 $\Delta$ and $y k u 80 \Delta$ mre $11 \Delta$ sir $4 \Delta$ rad52 $\Delta$ cells senesced and barely grew compared with that of $y k u 80 \Delta$ mre $11 \Delta$ cells (Figure S8A). Liquid senescence assay using these spores obtained consistent results, showing extremely slow proliferation for the $y k u 80 \Delta$ mre $11 \Delta$ rad52 $\Delta$ and $y k u 80 \Delta$ mre $11 \Delta$ sir $4 \Delta$ rad52 $\Delta$ cells in liquid culture following six successive passages (Figure S8B). These re-

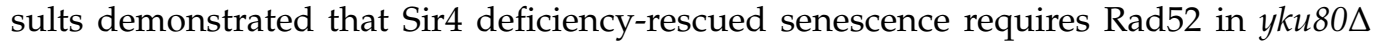
mre $11 \Delta$ cells.

To determine if Rad51-mediated sub-telomere $Y^{\prime}$ element recombination is required for Sir4 deficiency-induced rescue of senescence, we constructed the diploid strain het-

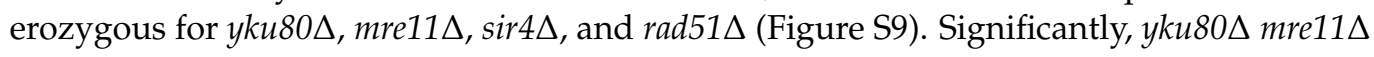


rad51 $\Delta$ and $y k u 80 \Delta$ mre $11 \Delta$ sir $4 \Delta$ rad51 $\Delta$ cells grew extremely slow with cell senescent phenotype at the first streakout comparable to that of $y k u 80 \Delta$ mre $11 \Delta$ cells at the third streakout, suggesting that Sir4 deficiency-rescued senescence requires Rad51 (Figure 1C).

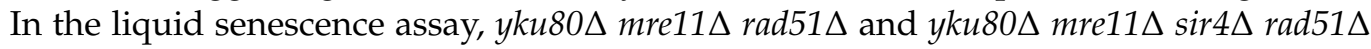
cells barely proliferated characteristic of cell senescence at the first passage when compared with that of $y k u 80 \Delta$ mre $11 \Delta$ and $y k u 80 \Delta$ mre $11 \Delta$ sir $4 \Delta$ cells, and $y k u 80 \Delta$ mre $11 \Delta$ rad51 $\Delta$ cells reached a cell density that was comparable to that of $y k u 80 \Delta$ mre11 $\Delta$ cells (Figure $1 D)$. Consistently, $y k u 80 \Delta$ mre $11 \Delta$ sir $4 \Delta$ rad51 $\Delta$ cells did not reach the cell density of $y k u 80 \Delta m r e 11 \Delta$ sir $4 \Delta$ cells at the sixth passage, further confirming that Rad51-mediated sub-telomere $\mathrm{Y}^{\prime}$ element recombination is indispensable to the telomere maintenance of $y k u 80 \Delta$ mre $11 \Delta \operatorname{sir} 4 \Delta$ cells (Figure 1D). These results demonstrated that Sir4 deficiency-rescued cell senescence

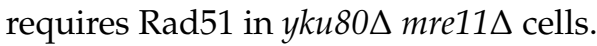

Rad59 facilitates the acquisition of $Y^{\prime}$ elements with short telomeres [26]. To determine if Rad59 is required for Sir4 deficiency to rescue senescence, we constructed the diploid

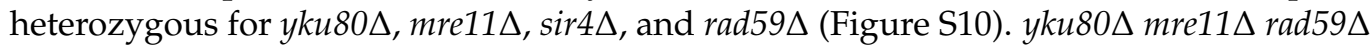
cells grew extremely slower than that of $y k u 80 \Delta$ mre $11 \Delta$ cells on the plate, similarly $y k u 80 \Delta$ mre $11 \Delta$ sir $4 \Delta$ rad59 $\Delta$ cells also grew slower than yku80 $\Delta$ mre $11 \Delta$ sir $4 \Delta$ cells following six

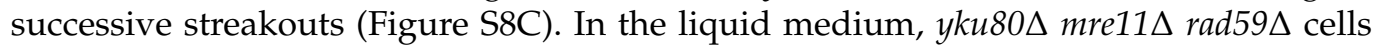
proliferated more slowly at the first three successive passages but reached comparable cell density at the sixth passage when compared with yku80 $\Delta$ mre11 $\Delta$ cells (Figure S8D). In addition, $y k u 80 \Delta$ mre $11 \Delta$ sir $4 \Delta$ rad59 $\Delta$ cells proliferated to an extent similarly to that of $y k u 80 \Delta$ mre $11 \Delta$ cells at the first three successive passages, and reached a comparable cell density to that of $y k u 80 \Delta m r e 11 \Delta \operatorname{sir} 4 \Delta$ at the sixth passage (Figure S8D). These data suggested that Sir4 deficiency-induced senescence-evasion is partially dependent upon Rad59 in yku80 $\mathrm{mre} 11 \Delta$ cells.

\subsection{Rif1, Rif1/2, But Not Rif2 Deficiency Suppresses Senescence}

To investigate a potential role of Rif1 and Rif2 inhibited telomerase lengthening in senescence, we constructed diploid strains heterozygous for $y k u 80 \Delta$, mre $11 \Delta$, rif1 $\Delta$, rif $2 \Delta$, and sir4 $\Delta$ with or without the $y k u 80-135 i$ allele (Figures S11-S13). As expected, deficiency of Rif1 or both Rif1/Rif2 lengthened telomeres by telomerase recruitment, rescuing senescence of $y k u 80 \Delta$ mre $11 \Delta$ cells following six successive streakouts, whereas yku80 $\Delta$ mre $11 \Delta$ rif $2 \Delta$

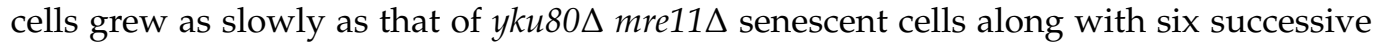
streakouts (Figure 2A and Figure S14). However, the cell densities of $y k u 80 \Delta$ mre $11 \Delta$ sir4 $\Delta$ and $y k u 80 \Delta$ mre $11 \Delta$ rif1 $\Delta$ were comparable, and the cell density of $y k u 80 \Delta$ mre $11 \Delta$ sir $4 \Delta$ rif1 $\Delta$ cells was in-between those of $y k u 80 \Delta$ mre $11 \Delta$ cells and $y k u 80 \Delta$ mre $11 \Delta$ sir $4 \Delta$ cells in liquid senescence assay $(p=0.26)$ (Figure $2 B$ ), suggesting that Rif1 deficiency compromises Sir4 deficiency-rescuing senescence in the $y k u 80 \Delta$ mre $11 \Delta$ cells by lengthening telomeres. In addition, the cell density of $y k u 80 \Delta$ mre11 $\Delta$ rif $2 \Delta$ cells was significantly lower than that of $y k u 80 \Delta$ mre $11 \Delta$ cells following six successive passages $(p=0.007)$ (Figure $2 \mathrm{C}$ ) and the cell density of $y k u 80 \Delta$ mre11 $\Delta$ sir $4 \Delta$ rif2 $\Delta$ cells was significantly lower than that of $y k u 80 \Delta$ mre $11 \Delta$ sir $4 \Delta$ cells $(p=0.005)$, suggesting that Rif2 deficiency alone is not sufficient to rescue the senescence of $y k u 80 \Delta$ mre11 $\Delta$ cells. Moreover, the cell densities of $y k u 80 \Delta$ mre $11 \Delta$ sir $4 \Delta$ rif $1 \Delta$ rif $2 \Delta$ penta mutant and $y k u 80 \Delta$ mre $11 \Delta$ sir $4 \Delta$ triple mutant cells were comparable following six successive passages $(p=0.6)$ (Figure 2D), and the cell density of $y k u 80 \Delta$ mre $11 \Delta$ rif1 $\Delta$ rif $2 \Delta$ cells was significantly higher than that of $y k u 80 \Delta$ mre $11 \Delta$ cells $\left(p=3.94 \times 10^{-5}\right)$ (Figure 2D), consistent with the data that deficiency of Rif1, or Rif1 plus Rif2, compromises the effect of Sir4 deficiency on rescuing senescence. 
A

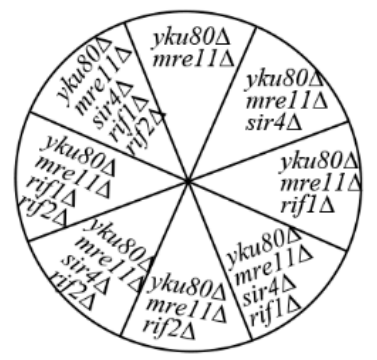

\#3

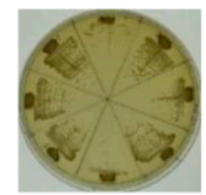

\#4

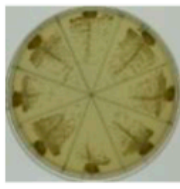

C

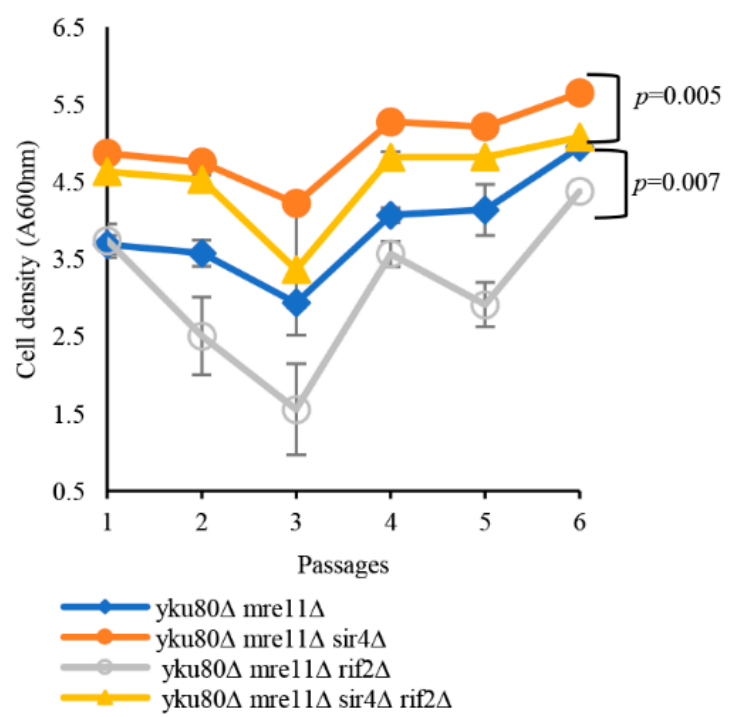

\#5

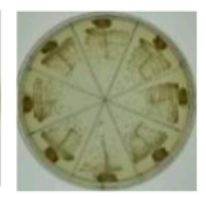

\#6
B
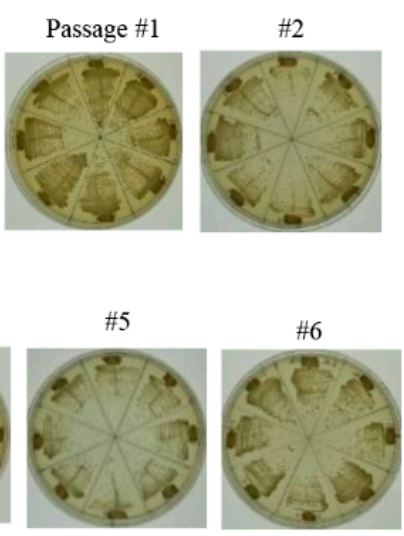

D
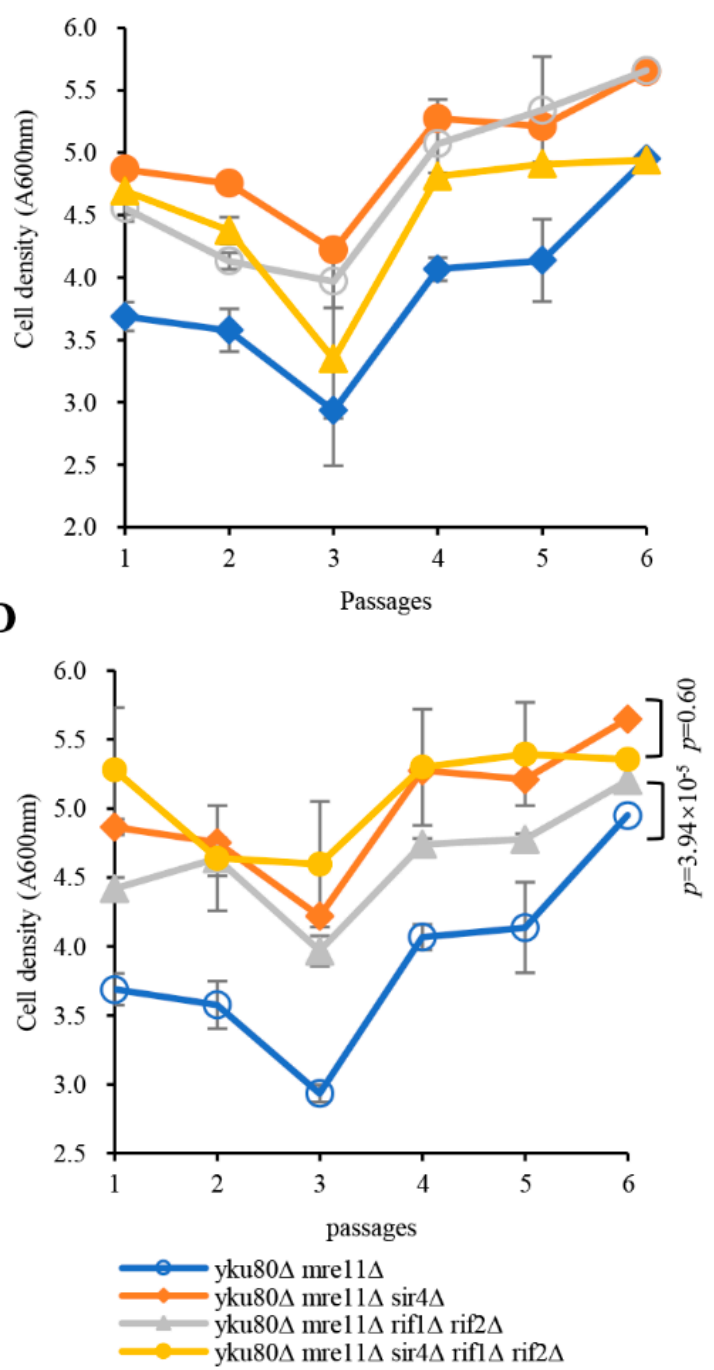

Figure 2. Effects of single and double deletions of RIF1 and RIF2 on the senescence of $y k u 80 \Delta m r e 11 \Delta$ and $y k u 80 \Delta m r e 11 \Delta$ sir $4 \Delta$ cells. (A) Spore $y k u 80 \Delta$ mre $11 \Delta$, yku80 $\Delta$ mre $11 \Delta$ sir $4 \Delta$, yku $80 \Delta$ mre $11 \Delta$ rif1 $\Delta$, yku80 $\Delta$ mre $11 \Delta$ sir $4 \Delta$ rif1 $\Delta$, yku $80 \Delta$ mre $11 \Delta$ rif $2 \Delta, y k u 80 \Delta$ mre $11 \Delta$ sir $4 \Delta$ rif $2 \Delta, y k u 80 \Delta$ mre $11 \Delta$ rif1 $\Delta$ rif $2 \Delta$, yku $80 \Delta$ mre $11 \Delta$ sir $4 \Delta$ rif1 $\Delta$ rif $2 \Delta$ were successively streaked on YPD plates every 2 days for six times. Images of photographed colony growth are from one of $4-5$ typical experiments. (B) Spores $y k u 80 \Delta$ mre $11 \Delta$, yku80 $\Delta$ mre11 $\Delta$ sir $4 \Delta$, yku80 $\Delta$ mre11 $\Delta$ rif1 $\Delta$, and $y k u 80 \Delta$ mre $11 \Delta$ sir $4 \Delta$ rif1 $\Delta$ cells. (C) $y k u 80 \Delta$ $m r e 11 \Delta, y k u 80 \Delta$ mre $11 \Delta$ sir $4 \Delta, y k u 80 \Delta$ mre $11 \Delta$ rif $2 \Delta$, and $y k u 80 \Delta$ mre $11 \Delta$ sir $4 \Delta$ rif2 $\Delta$. (D) $y k u 80 \Delta m r e 11 \Delta, y k u 80 \Delta m r e 11 \Delta$ sir $4 \Delta, y k u 80 \Delta$ mre $11 \Delta$ rif1 $\Delta$ rif $2 \Delta$, and $y k u 80 \Delta$ mre11 $\Delta$ sir $4 \Delta$ rif1 $\Delta$ rif $2 \Delta$ cells were cultured in liquid YPD medium with initial concentration of $\mathrm{A} 600 \mathrm{~nm}=0.01$ for around $20 \mathrm{~h}$ and followed by $\mathrm{A} 600 \mathrm{~nm}$ measurement, and re-dilution was made every $20 \mathrm{~h}$. Results are mean $\pm \operatorname{SEM}(n=4-5)$.

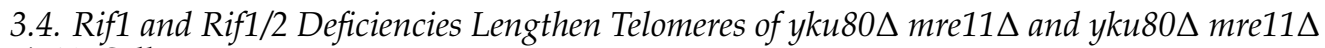
sir4 $\Delta$ Cells

To investigate the mechanism by which Sir4 and Rif1 deficiencies rescue the senescence of $y k u 80 \Delta$ mre11 $\Delta$ cells, and Rif1 deficiency sabotages the effect of Sir4 deficiency on rescue

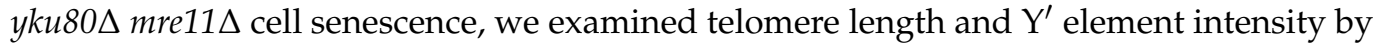
Southern blot of spores with or without Rif1/2, Sir3/4, Yku80, and Mre11. Notably, Rif1 and Rif2 deficiencies produced longer telomeres after six successive streakouts (Figure 3A, lanes 3-4 versus lane 2), and the longer telomeres were eliminated by SIR4 and MRE11 
deletions (Figure 3A, lanes 5-6 versus lane 3-4), consistent with the notion that Sir4-Yku80 interaction and MRX-ssDNA mediate telomere telomerase recruitment that is inhibited by Rif1 and Rif2. Deletions of RIF1 and RIF2 (rif1 $\Delta$ rif2 1 ) plus the $y k u 80-135 i$ allele and mre $11 \Delta$ resulted in a severe blockade of telomere lengthening with observable shortest telomeres (Figure 3A, lanes 7-8), consistent with the essential roles of Yku80-Tlc1 interaction and MRXssDNA for telomerase recruitment. However, deletion of SIR4 led to higher amplification

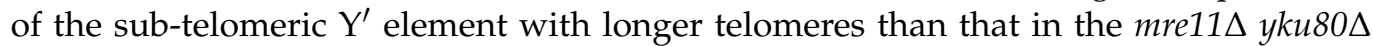
cells (Figure 3A, lanes 19-20 versus 21-22; Figure S15A,B). The sub-telomeric $Y^{\prime}$ element amplification induced by SIR4 deletion in yku80 $\Delta$ mre $11 \Delta$ cells was significantly reduced by deletions of RIF1 and RIF2 (Figure 3A, lanes 19-20 versus lanes 11-12, 21-22 versus 13-14), suggesting that Sir4 and Rif1/2 are reciprocally involved in an opposing negative and positive regulation of sub-telomeric $\mathrm{Y}^{\prime}$ element recombination respectively. Moreover, the effects of RIF1 or RIF2 deletion on telomere lengths and $\mathrm{Y}^{\prime}$ element recombination were examined after six successive streakouts (Figure 3B). RIF1 and RIF2 double deletions as well as RIF1 (but not RIF2) single deletion suppressed $\mathrm{Y}^{\prime}$ element recombination in $y k u 80 \Delta$ mre $11 \Delta$ cells (Figure 3A, lanes 13-14 versus lanes 21-22; Figure 3B, lanes 29-30 versus lanes 13-14).

\subsection{Sir4 Deficiency Enhances, whereas Rif1 or Rif1/2 Deficiency Suppresses, $Y^{\prime}$ Element Amplification}

Next, we systematically and quantitatively examined sub-telomere $Y^{\prime}$ element amplification by qSACH [39] in the various strains with or without SIR4 or RIF1 deletion. $\mathrm{Y}^{\prime}$ element copy number significantly increased in $y k u 80 \Delta$ mre $11 \Delta$ compared with WT $\left(p=3.02 \times 10^{-9}\right)$ following six successive passages (Figure $\left.4 \mathrm{~A}\right)$, consistent with published results [22]. Accordingly, yku80 $\Delta$ mre $11 \Delta$ sir $4 \Delta$ cells showed significantly increased $\mathrm{Y}^{\prime}$ element copy numbers than yku $80 \Delta$ mre $11 \Delta$ cells $\left(p=4.60 \times 10^{-4}\right)$ (Figure $\left.4 \mathrm{~A}\right)$. Inactivation of Sir3 $\left(p=4.41 \times 10^{-4}\right)$, but not inactivation of Sir2, recapitulated the effects of Sir4 deficiency

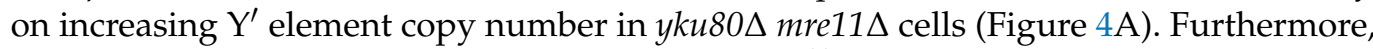
we found that inactivation of Rif1 $\left(p=1.19 \times 10^{-11}\right)$, Rif2 $(p=0.02)$, or both Rif1 and Rif2 $\left(p=6.09 \times 10^{-9}\right)$ significantly decreased $\mathrm{Y}^{\prime}$ element copy numbers compared with

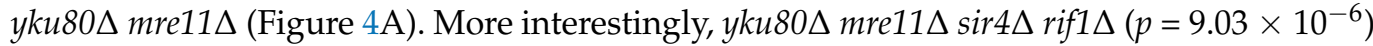
and $y k u 80 \Delta$ mre $11 \Delta$ sir $4 \Delta$ rif1 $\Delta$ rif $2 \Delta\left(p=9.63 \times 10^{-4}\right)$ (but not $y k u 80 \Delta$ mre $11 \Delta$ sir $4 \Delta$ rif $2 \Delta$ $(p=0.49))$ cells consistently showed significantly decreased $Y^{\prime}$ element copy numbers than yku80 $\Delta$ mre $11 \Delta$ sir $4 \Delta$ cells (Figure $4 \mathrm{~A}$ ).

\subsection{Rif1 or Rif1/2 Deficiency Compromises sir4 $\Delta$-induced $Y^{\prime}$ Element Recombination}

$y k u 80 \Delta$ mre $11 \Delta$ rif1 $\Delta$ rif $2 \Delta$ cells had longer telomeres than $y k u 80 \Delta$ mre $11 \Delta$ cells, suggesting that rif1 $\Delta$ rif $2 \Delta$ increased telomerase recruitment in $y k u 80 \Delta$ mre $11 \Delta$ (known as telomerase recruitment failure) cells. However, yku80 $\Delta$ mre $11 \Delta$ sir $4 \Delta$ rif1 $\Delta$ rif $2 \Delta$ cells had lower $\mathrm{Y}^{\prime}$ element recombination that $y k u 80 \Delta$ mre $11 \Delta$ sir $4 \Delta$ cells (Figure $4 \mathrm{~A}$ ), consistent with a role of rif1 $\Delta$ rif2 $\Delta$ in lengthening telomeres to suppress sub-telomere recombination. Nevertheless, $\mathrm{Y}^{\prime}$ element intensity in $y k u 80 \Delta$ mre $11 \Delta$ sir $4 \Delta$ rif1 $\Delta$ rif $2 \Delta$ cells was still higher than that of $y k u 80 \Delta$ mre $11 \Delta$ cells, suggesting that rif1 $\Delta$ rif $2 \Delta$ mediated telomere lengthening incompletely suppresses the $\operatorname{sir} 4 \Delta$-induced $Y^{\prime}$ element amplification, i.e., Sir4-deficit had stronger effects on $\mathrm{Y}^{\prime}$ element recombination than Rif1/2-deficiencies.

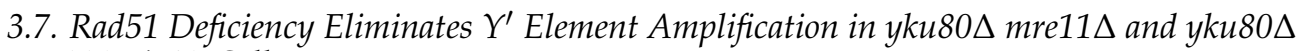 mre11 1 sir $4 \Delta$ Cells}

To further confirm that Sir4 deficiency mediated rescue of $y k u 80 \Delta$ mre11 $\Delta$ cell senescence was due to Rad52/Rad51 mediated $Y^{\prime}$ element amplification, we examined $Y^{\prime}$ element amplification in $y k u 80 \Delta$ mre11 $\Delta$ cells with or without RAD52 or RAD51 deletion. Our results showed that the $\mathrm{Y}^{\prime}$ element amplification in $y k u 80 \Delta$ mre $11 \Delta \mathrm{rad} 52 \Delta, y k u 80 \Delta$ mre $11 \Delta$ rad51 $\Delta, y k u 80 \Delta$ mre $11 \Delta \operatorname{sir} 4 \Delta$ rad52 $\Delta$, and $y k u 80 \Delta$ mre $11 \Delta$ sir $4 \Delta$ rad51 $\Delta$ cells was 
completely sabotaged (Figure 4B). These data indicate that Sir4 deficiency rescues $y k u 80 \Delta$ mre11 $\Delta$ cell senescence by increasing Rad52/Rad51-mediated $Y^{\prime}$ element amplification.

A
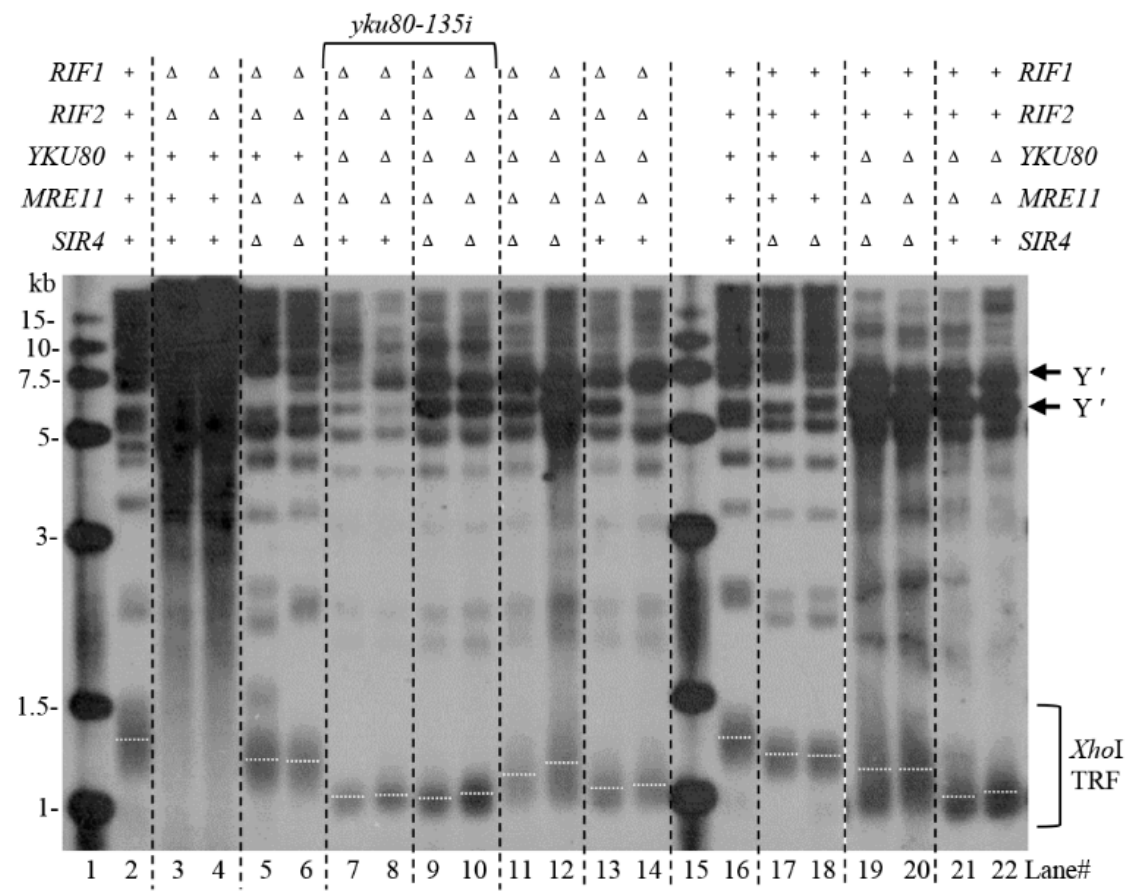

B
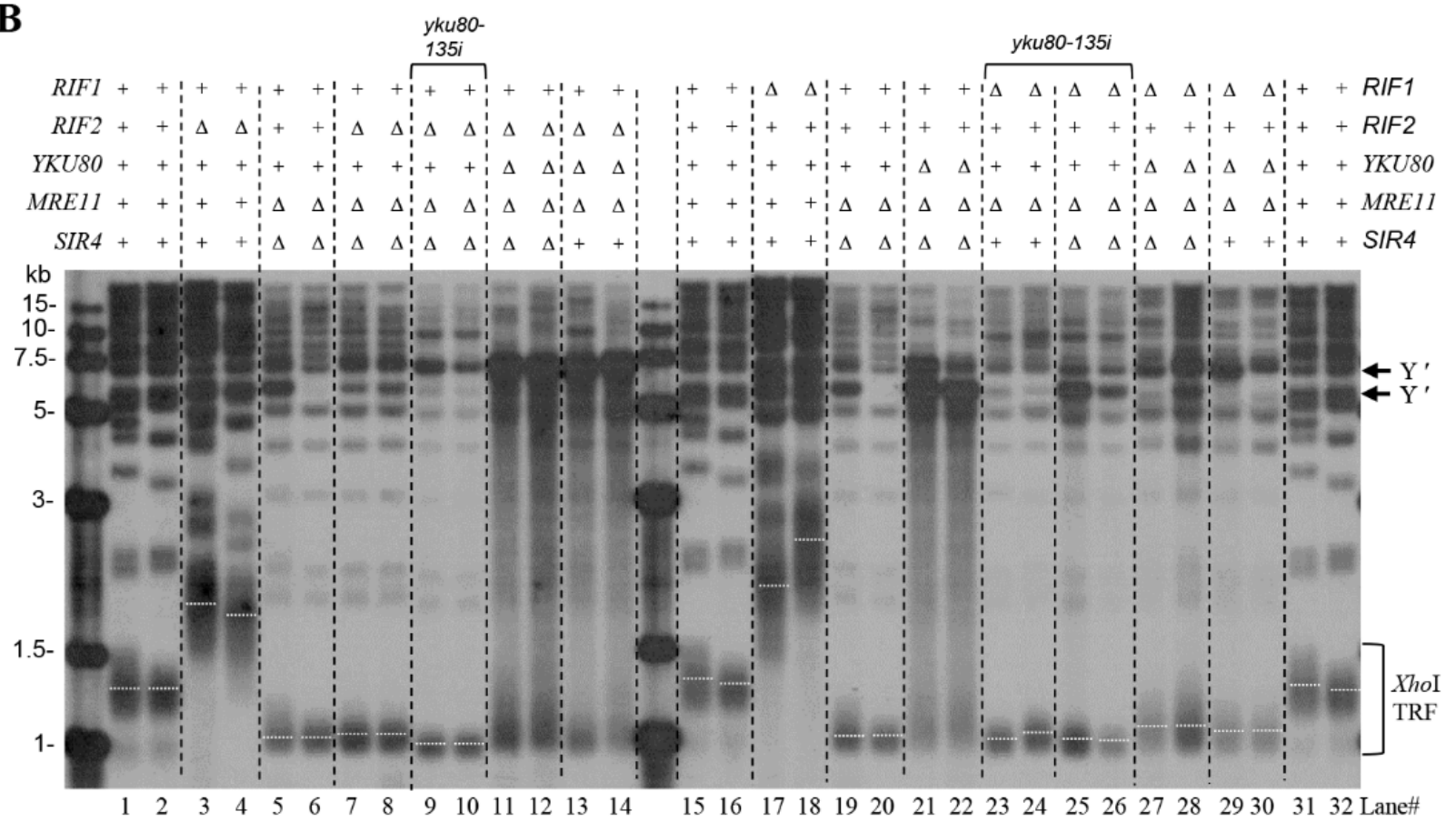

Figure 3. Telomere length analysis in various mutants with or without SIR4, RIF1, or RIF2 deletion in yku80 $m$ re $11 \Delta$ cells. (A) Spore WT, rif1 $\Delta$ rif $2 \Delta$, rif1 $\Delta$ rif2 $\Delta$ mre11 $\Delta$ sir $4 \Delta$, rif1 $\Delta$ rif $2 \Delta$ mre $11 \Delta$ yku80 $\Delta$ (yku80-135i), rif1 $\Delta$ rif $2 \Delta$ mre $11 \Delta$ y $k u 80 \Delta$

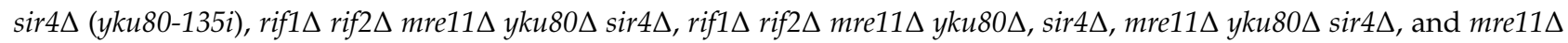

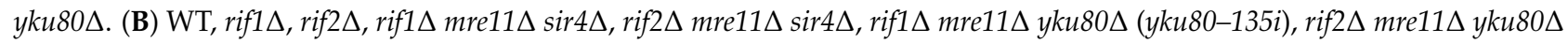

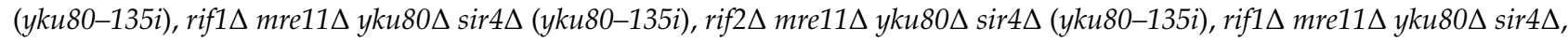

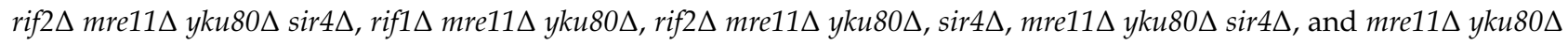
spore cells after successive six streakouts on plates every 3-4 days were collected for telomere length Southern blot analysis. 


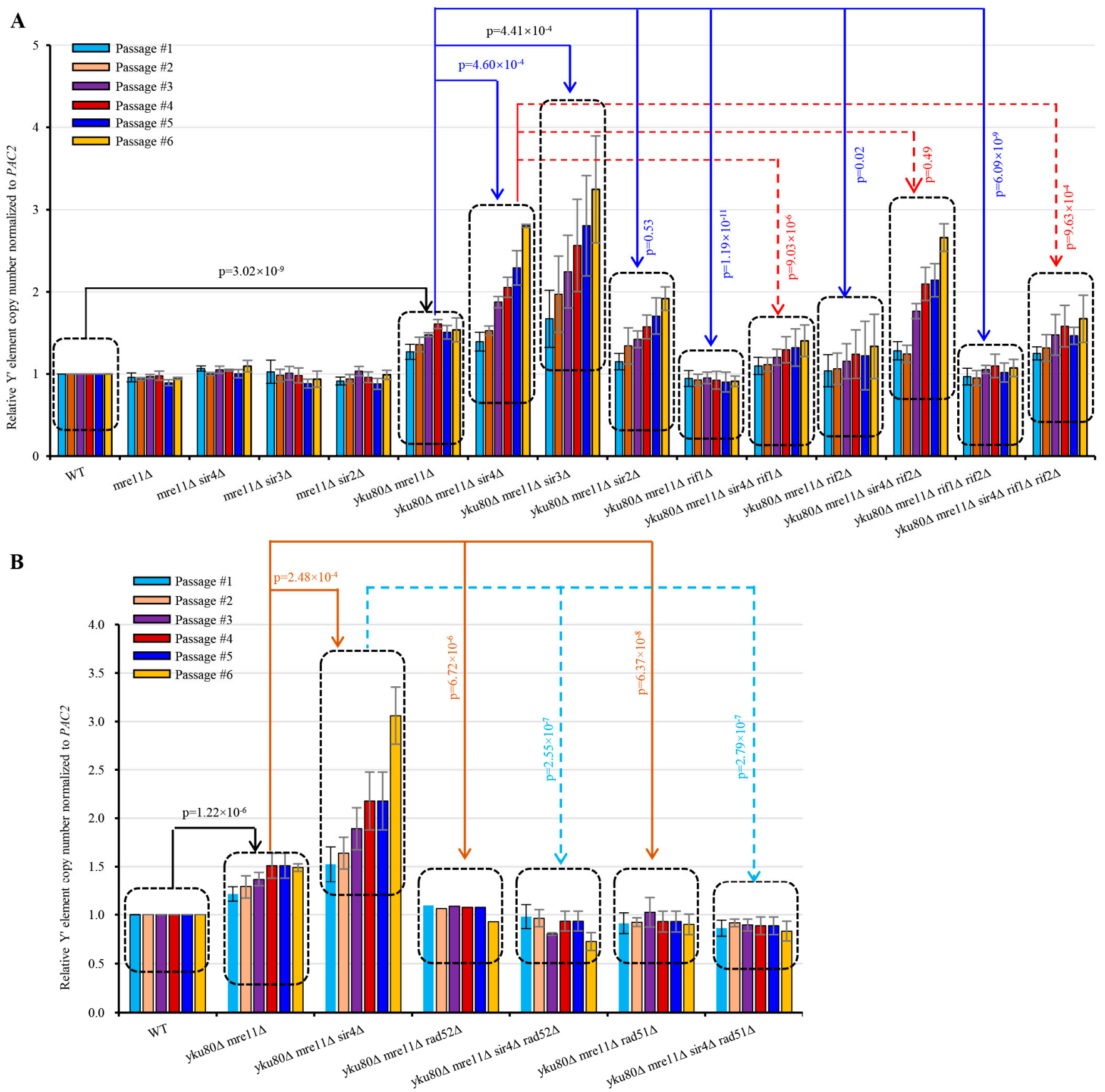

Figure 4. Effects of SIR2, SIR3, SIR4, RIF1, RIF2, RIF1/2, RAD52, RAD51, and RAD59 deletions on the $Y^{\prime}$ element amplification of $y k u 80 \Delta$ mre $11 \Delta$ and of $y k u 80 \Delta$ mre $11 \Delta$ sir $4 \Delta$ cells. (A) Spore cells $y k u 80 \Delta$ mre $11 \Delta$ and $y k u 80 \Delta m r e 11 \Delta$ sir $4 \Delta$ with or without RIF1, RIF2, or RIF1/2 deletions. (B) Spore cells yku80 $\operatorname{mre} 11 \Delta$ and $y k u 80 \Delta$ mre $11 \Delta$ sir4 $\Delta$ with or without RAD51, RAD52, or RAD59 deletion were passaged successively in liquid medium every $20 \mathrm{~h}$. Genomic DNAs were isolated which was followed by qSACH analyses of $\mathrm{Y}^{\prime}$ element copy number. Data are $\pm \operatorname{SEM}(n=5)$.

3.8. Increased TERRA and Loss of Telomere Perinuclear Localization Contributes to the $Y^{\prime}$ Element Amplification Induced by Sir4 Deficiency

PAF1 complex epigenetically inhibits telomere transcription of TERRA whereas paf1 $\triangle$ and $\operatorname{ctr} 9 \Delta$ cells produce higher TERRA in a Sir4-independent manner [40], we determined if the epigenetic regulation of telomere transcription by Sir4 might be related to sub-telomere $\mathrm{Y}^{\prime}$ amplification regulated by Sir4 using diploid strains heterozygous for $y k u 80 \Delta \mathrm{mre} 11 \Delta$ $\operatorname{sir} 4 \Delta$ paf1 $\Delta$ and $y k u 80 \Delta$ mre $11 \Delta$ sir $4 \Delta$ ctr9 $\Delta$ (Figures S16 and S17). Spore cells carrying paf1 $\Delta$ and $\operatorname{ctr} 9 \Delta$ alleles had extremely slow growth phenotype (Figures S16 and S17), 
therefore these spore cells were streaked onto fresh YPD plates and allow them to grow 4 days. Remarkably, sub-telomere $Y^{\prime}$ element abundance in $y k u 80 \Delta$ mre $11 \Delta$ sir $4 \Delta$ paf1 $\Delta$ $\left(p=1.64 \times 10^{-9}\right)$ cells or $y k u 80 \Delta$ mre $11 \Delta$ sir $4 \Delta$ ctr $9 \Delta$ cells $\left(p=1.63 \times 10^{-8}\right)$ was increased to the levels $3-5$ folds higher than that of yku $80 \Delta$ mre11 $\Delta$ sir $4 \Delta$ cells during six successive streakouts (Figure 5A), suggesting that paf $1 \Delta / \operatorname{ctr} 9 \Delta$ alleles mediate the $Y^{\prime}$ element amplification. The striking potentiating effect of Paf1/Ctr9 loss on Sir4 deficiency-induced sub-telomere $\mathrm{Y}^{\prime}$ element amplification reflected an intimate role of PAF1/Ctr9 epigenetic regulation of sub-telomere $\mathrm{Y}^{\prime}$ homologous recombination by a mechanism parallel with

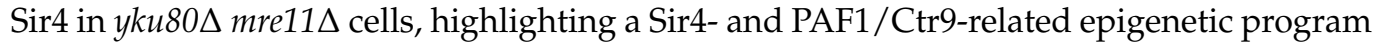
in the regulation of sub-telomere homologous recombination and telomere transcription in a coordinated manner.
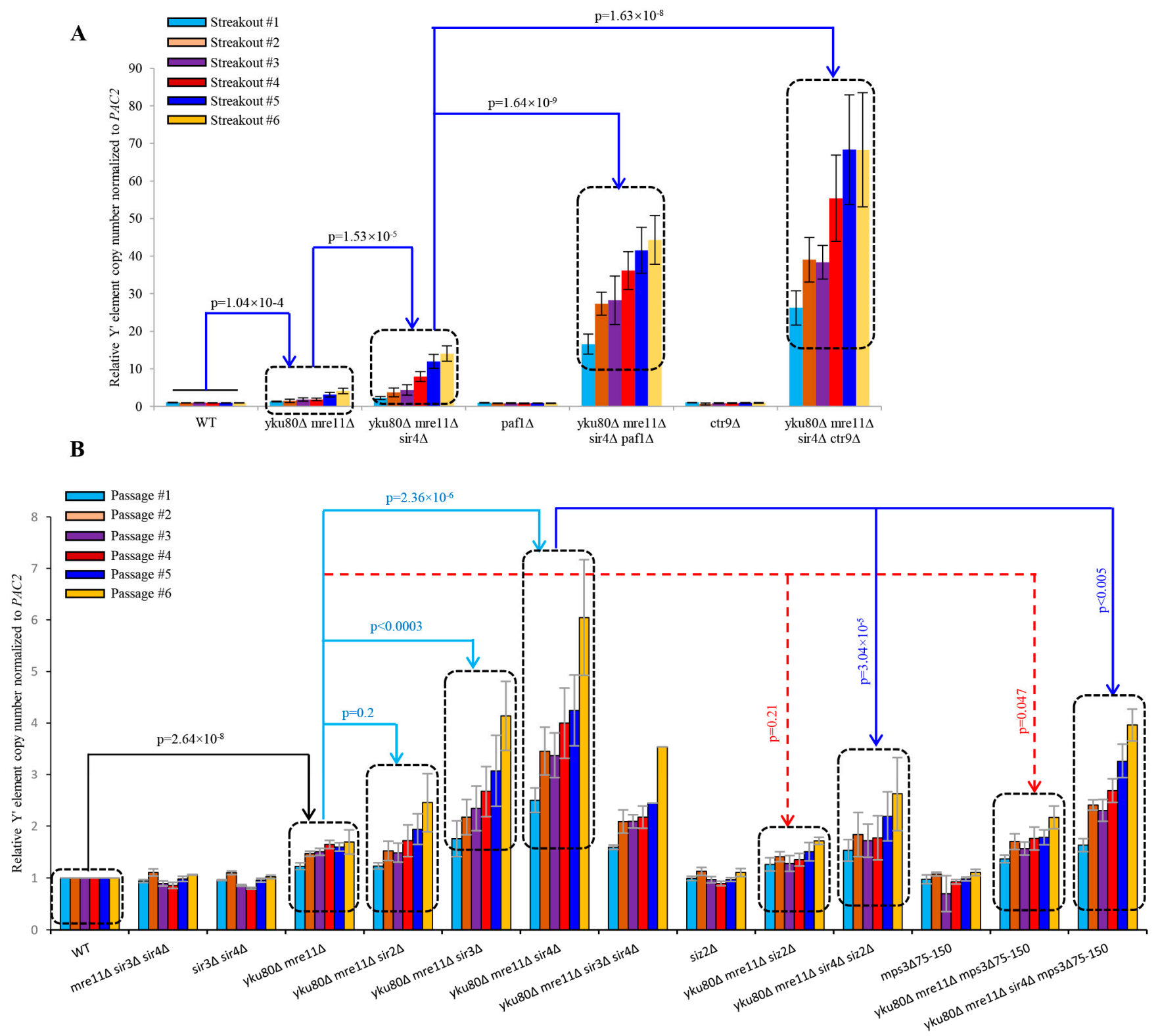

Figure 5. Effects of paf1 $\Delta$, ctr9 $\Delta$, siz2 $\Delta$ or mps3 $\Delta 75-150$ allele on the $Y^{\prime}$ element amplification of $y k u 80 \Delta$ mre $11 \Delta$ and $y k u 80 \Delta$

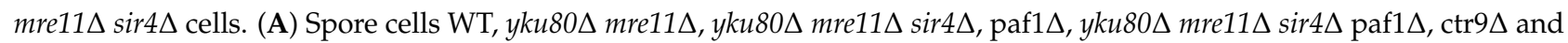
$y k u 80 \Delta$ mre $11 \Delta$ sir $4 \Delta \operatorname{ctr} 9 \Delta$ were successively streaked six times on YPD plates every 4 days (B) Spore cells with or without siz2 $\Delta$ or mps3 $\Delta 75-150$ allele were successively passaged six times in liquid YPD medium every $20 \mathrm{~h}$. Genomic DNAs were isolated and followed by qSACH analyses of $\mathrm{Y}^{\prime}$ element copy numbers. Data are $\pm \mathrm{SEM}(n=3-5)$. 
To determine if Sir4-mediated telomere perinuclear localization [41,42] might be involved in the repressive mechanisms of $Y^{\prime}$ element amplification, we constructed the diploid strains heterozygous for $y k u 80 \Delta$ mre $11 \Delta$ sir $4 \Delta$ mps $3 \Delta 75-150$ for comparisons with that of $y k u 80 \Delta, m r e 11 \Delta$ sir $4 \Delta$ siz2 $\Delta$ (Figures S18 and S19). Loss of Siz2, a PIAS-like SUMO E3 ligase that sumoylates both Yku80 and Sir4 and promotes telomere anchoring to the nuclear envelope [42], did not significantly increase $Y^{\prime}$ element amplification $(p=0.21)$ in $y k u 80 \Delta$ mre $11 \Delta$ cells following six successive passages (Figure 5B), suggesting that loss of perinuclear envelope anchoring alone is not sufficient to increase $Y^{\prime}$ element amplification in $y k u 80 \Delta$ mre $11 \Delta$ cells. However, introduction of the mps3 $\Delta 75-150$ allele in yku $80 \Delta$ mre $11 \Delta$ cells to specifically disrupt the interaction between Mps3 (a Sad1-UNC-84 domain protein that is required to anchor telomeres at the nuclear envelope) and Sir4 [41] significantly increased $Y^{\prime}$ element copy numbers $(p=0.047)$ (Figure 5B), suggesting that telomere perinuclear location mediated by Sir4 interaction with mps3's acidic domain (amino acids 75-150) plays an important inhibitory role in $Y^{\prime}$ element amplification in the absence of Yku80 and Mre11. Furthermore, the $\mathrm{Y}^{\prime}$ element copy numbers in yku80 $\Delta$ mre11 $\Delta \operatorname{sir} 4 \Delta$ mps3 $\Delta 75-150$ cells were significantly lower than that of yku80 $\Delta \operatorname{mre} 11 \Delta \operatorname{sir} 4 \Delta(p<0.005)$ but in-between of that in yku $80 \Delta$ mre11 $\Delta \operatorname{sir} 4 \Delta$ and yku80 $\Delta$ mre $11 \Delta$ mps3 $\Delta 75-150$ cells, consistent with a notion that Sir4 deficiency and mps3 $\Delta 75-150$ allele stimulate $Y^{\prime}$ element amplification in the same pathway by releasing telomere perinuclear location through unleashing an epigenetic heterochromatin program in the deficiencies of both Yku80 and Mre11.

\section{Discussion}

We demonstrate a pivotal role of Sir4 in suppressing homologous recombinationdependent sub-telomere $Y^{\prime}$ element amplification in a telomerase-positive sub-telomere recombination cell senescence model. Sir4 deficiency activates a significant increase in sub-telomere $Y^{\prime}$ amplification intensity and frequency to lengthen telomeres and divert cell senescence in the yeast strains deficient of Yku80 and MRX that mediate telomerase recruitment and DNA repair pathways respectively $[6,7,14,15,43]$. Given the intermediate role in mediating telomerase recruitment as reported recently [6,7], Sir4 emerges to maintain telomere homeostasis by two distinct mechanisms: telomerase recruitment and suppression of sub-telomere $Y^{\prime}$-element amplification. Although Sir2 and Sir3 are recruited to telomeres similarly by Sir4, Sir3, but not Sir2, they operate along with Sir4 to repress sub-telomere $\mathrm{Y}^{\prime}$ element homologous recombination, with Sir3 deficiency resembling that of Sir4 in rescuing cell senescence by promoting $\mathrm{Y}^{\prime}$ element amplification. Consistently, similar scenarios for the roles of telomerase recruitment of Sir2, Sir3, and Sir4 were reported previously, with Sir2 playing a minor one [6]. The function of Sir4 and Sir3 in the negative regulation of sub-telomere homologous recombination is consistent with the roles of the Sir protein complex in epigenetic silencing and maintaining telomere heterochromatin as shown previously [30]. Our findings suggest the meaningfulness of exploiting sub-telomere heterochromatin homologous recombination silencer Sir4 to link recruiting telomerase. So, when Sir4 deficiency occurs with very short telomeres, sub-telomere homologous recombination would become activated simultaneously to prevent telomere shortening for survival and proliferative potential.

The mechanism by which Sir4 deficiency triggers sub-telomere $Y^{\prime}$ element homologous recombination appears to be mediated by unchecking the heterochromatin inhibitory control over an access of homologous recombination machineries (Figure 6A,B). Evidence supporting this conclusion is three-fold. First, we find that the paf1 $\Delta$ or $\operatorname{ctr} 9 \Delta$ allele that increases telomeric DNA transcription for TERRA significantly stimulates and potentiates Sir4 deficiency-induced sub-telomere $Y^{\prime}$-element amplification following successive streakouts (Figure 5A), indicating PAF1 complex functions in parallel to Sir4 in silencing sub-telomere $Y^{\prime}$ element amplification. Second, consistent with unchecking the heterochromatin network suppressing sub-telomere $\mathrm{Y}^{\prime}$ element homologous recombination, we find that disrupting Sir4 interaction with Mps3 to inhibit Sir4-dependent telomere perinuclear 
positioning activates sub-telomere $\mathrm{Y}^{\prime}$ element amplification (Figure 5B). These findings are consistent with previous studies that Sir4 mediates telomere anchoring at the nuclear envelope [41] and that Sir4 loss disrupts the telomere fold-back structures [44,45] redistributing telomeres with SUN domain-containing protein Mps3 interacting with Yku70/80-Tlc1-Est1. In addition, we find that Rad52, Rad51, and partially Rad59 are required in mediating Sir4 removal-induced sub-telomeric $Y^{\prime}$-element amplification, highlighting that the mechanism of Sir4 deficiency-induced sub-telomere $Y^{\prime}$-element amplification is not an isolated event, but belongs to an evolved overall cellular program mediated by Rad52, Rad51, and partially Rad59 in a coordinated manner with telomere transcription and repositioning from anchoring nuclear envelope. Although PAF1 suppression of telomeric DNA transcription for TERRA is independent of Sir4 [40], our findings that PAF1 deficiency potentiates Sir4 deficiency-induced sub-telomere $Y^{\prime}$ amplification suggest that PAF1 and Sir4 are related in epigenetic suppressing sub-telomere homologous recombination. Given that the effects between removing Sir4 and disrupting Sir4 interaction with Mps3 converges on sub-telomere $\mathrm{Y}^{\prime}$ amplification, it is likely that Sir4 regulates sub-telomere $\mathrm{Y}^{\prime}$-element homologous recombination suppression by mechanisms involving the modulation of telomere nuclear periphery positioning at least in part in trans.

More interestingly, Rif1 and Rif2 are recruited to duplex telomeres by Rap1 that recruits Sir4, offering a potential cis mechanism for Rif1 and Rif2 to regulate Sir4-induced subtelomere $Y^{\prime}$-element homologous recombination silencing [34]. By genetic deletions of RIF1 and RIF2, we demonstrate that Sir4 and Rif1 undergo functional interaction with opposing roles in negative and positive regulations of sub-telomere $Y^{\prime}$ element homologous recombination respectively (Figure 6A,B). We show that Rif1 and Rif2 underpin sub-telomeric homologous recombination (Figure 4A) and deficiencies inhibit Sir4 deficiency-induced sub-telomeric $\mathrm{Y}^{\prime}$-element amplification by lengthening telomeres (Figures 3A, 4 and 6B). Finally, the identifications of Rif1/Rif2 in mediating, and Sir4 in suppressing, sub-telomere $\mathrm{Y}^{\prime}$ element homologous recombination are remarkable in that Rif1/Rif2 and Sir4/Sir3 respectively inhibits and stimulates telomerase recruitment to lengthen telomeres. The dual roles for each of the two proteins in both regulating telomerase recruitment and sub-telomere $Y^{\prime}$ amplification suggest that Sir4 and Rif1 are used to protecting one primary mechanism of telomerase lengthening of telomeres while inhibiting another second mechanism as a backup until unless telomerase recruitment or availability is compromised.

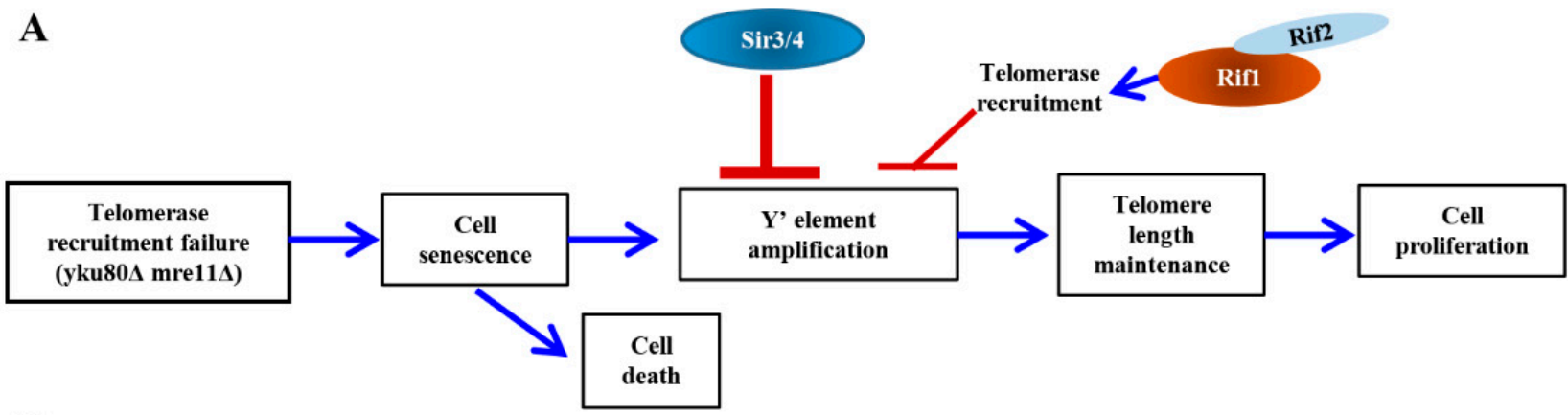

Figure 6. Cont. 


\section{B}

yku80 $\Delta$ mre11 $\Delta$
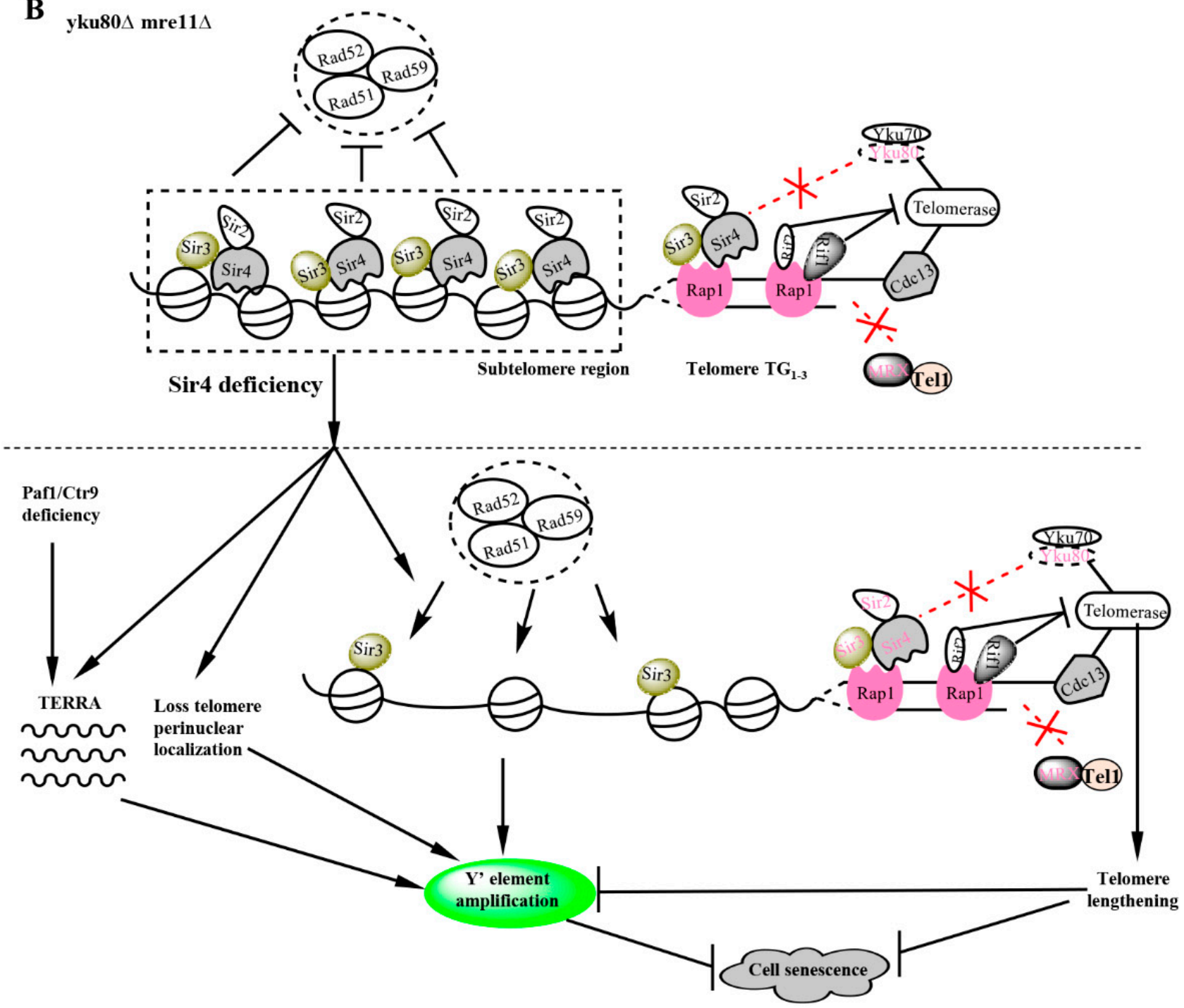

Figure 6. Schematic showing the roles of Sir3/4 and Rif1/2 and their relationships to the up- and down-stream elements in the rescuing pathway of senescence induced by Yku80 and Mre11 deficits. (A) Summary of effects of Sir3/4 and Rif1/2 on sub-telomere $\mathrm{Y}^{\prime}$ element amplification and senescence of $y k u 80 \Delta$ mre11 $\Delta$ cells, a telomerase-positive sub-telomererecombination model. (B) A schematic picture showing the molecular roles of Rap1, Sir2/3/4, Yku80/Yku70, Rif1/2, Yku80, Mre11, Tel1, Rad52/Rad51/Rad59, telomerase, Cdc13 at sub-telomere and telomere ends. yku80 $\Delta$ mre11 $\Delta$ cells define a telomerase-positive sub-telomere-recombination model, following cell divisions, their telomeres do not reach critical short length but very short, some cells go through senescence characterized with reduced cell numbers during subculturing and sub-telomere $Y^{\prime}$ element amplification, which might be due to disrupted Sir4-Yku80-Tlc1 telomerase-recruitment pathway and Rif1/2-inhibited-MRX-mediated ssDNA generation for Cdc13 loading, and pervasive action of exonuclease ExoI at telomere ends. Sir4 deficiency increases $Y^{\prime}$ element amplification frequency and rescues the senescence of $y k u 80 \Delta$ $m r e 11 \Delta$ cells by disrupting telomere perinuclear localization, loss of telomere heterochromatin structure, and increasing TERRA transcription. In parallel, Paf1 or Ctr9 deficiency increases TERRA transcription in a Sir4-independent manner, but interestingly, further increases $Y^{\prime}$ element amplification in sir4 $\Delta$ cells. Sir4 deficiency results in changes of sub-telomere structures that might have increased the access of Rad51/Rad52/Rad59 complex mediated machinery into sub-telomere region to promote $\mathrm{Y}^{\prime}$ element amplification.

Supplementary Materials: The following are available online at https:/ / www.mdpi.com/article / 10.3390/cells10040778/s1. Table S1: Yeast strains and plasmids used in this study; Table S2: Combination of primers and templates to amplify gene-specific KO cassettes; Table S3: Primers used

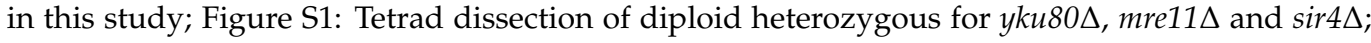
Figure S2: Tetrad dissection of two diploid strains heterozygous for $y k u 80 \Delta$ mre $11 \Delta \operatorname{sir} 2 \Delta$ and $y k u 80 \Delta$ 
mre $11 \Delta$ sir3 $\Delta$; Figure S3: Effects of SIR3 or SIR2 deletion on cell senescence of $y k u 80 \Delta$ mre $11 \Delta$ cells;

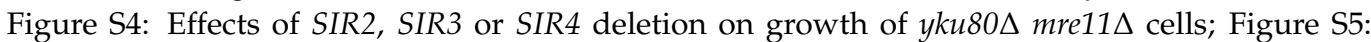
Tetrad dissection diploid heterozygous for $y k u 80 \Delta$ mre $11 \Delta \operatorname{sir} 3 \Delta \operatorname{sir} 4 \Delta$; Figure S6: Effects of SIR3 and SIR4 deletions on cell senescence of $y k u 80 \Delta$ mre11 $\Delta$ cells; Figure S7: Tetrad dissection of diploid heterozygous for $y k u 80 \Delta$, mre $11 \Delta$ sir $4 \Delta$ and rad52 $\Delta$; Figure S8: Senescence analysis for $y k u 80 \Delta$ mre $11 \Delta$ and $y k u 80 \Delta$ mre $11 \Delta$ sir $4 \Delta$ cell with/without rad52 $\Delta$ or rad59 $\Delta$; Figure S9: Tetrad dissection of diploid heterozygous for $y k u 80 \Delta$, mre $11 \Delta$ sir $4 \Delta$ and rad51 $\Delta$; Figure S10: Tetrad dissection of diploid heterozygous for $y k u 80 \Delta, m r e 11 \Delta$ sir4 $\Delta$ and rad59 $\Delta$; Figure S11: Tetrad dissection of diploid heterozygous for rif1 $\Delta$ rif $2 \Delta$ mre $11 \Delta$ yku $80 \Delta$ and sir $4 \Delta$; Figure S12: Tetrad dissection of diploid heterozygous for rif1 $\Delta$ rif $2 \Delta$ mre $11 \Delta$ y $k u 80 \Delta$ and sir4 $\Delta$; Figure S13: Tetrad dissection of diploid heterozygous for rif1 $\Delta$ rif $2 \Delta$ mre11 $\Delta$ yku80 $\Delta$ and sir $4 \Delta$ carrying pRS315-yku80-135i; Figure S14: Successive streakouts of spores with different genotypes; Figure S15: Effects of Sir4 deficiency on $\mathrm{Y}^{\prime}$ element amplification of $y k u 80 \Delta$ mre11 $\Delta$ cells; Figure S16: Tetrad dissection of diploid strain heterozygous for $y k u 80 \Delta$ mre $11 \Delta$ sir $4 \Delta$ ctr $9 \Delta$; Figure S17: Tetrad dissection of diploid strain heterozygous

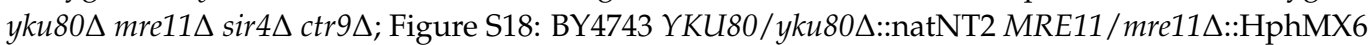
SIR4 / sir4 $\Delta:: H I S 3 M X 6$ SIZ2 / siz2 $\Delta:: K a n M X 6$ tetrad dissection; Figure S19: Tetrad dissection of BY4743

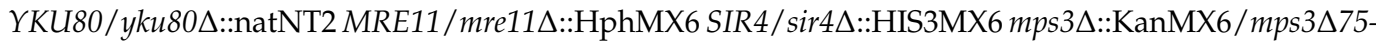
150::LEU2.

Author Contributions: Conceptualization, J.L. and J.-P.L.; methodology, J.L.; software, J.L.; validation, J.L., X.H., L.W., C.-Y.L. and J.-P.L.; formal analysis, J.L.; investigation, J.L., X.H., L.W., C.-Y.L.; resources, J.L., X.H., L.W., C.-Y.L. and J.-P.L.; data curation, J.L.; writing-original draft preparation, J.L.; writing-review and editing, J.L. and J.-P.L.; visualization, J.L.; project administration, J.L.; funding acquisition, J.L. and J.-P.L. All authors have read and agreed to the published version of the manuscript.

Funding: This work was supported by the National Natural Science Foundation of China (31501110 to J.L. and 81530039 to J.P.L.), the National Key Research and Development Program of China (2018YFC2000100 to J.P.L.), Start-up Research Program of Hangzhou Normal University (2018QDL010 to J.L.), China Postdoctoral Science Foundation (2014M551470 to J.L.) and Postdoctoral Research Program of Shanghai Institutes for Biological Sciences, Chinese Academy of Sciences (2014KIP305 to J.L.).

Institutional Review Board Statement: Not applicable.

Informed Consent Statement: Not applicable.

Data Availability Statement: Not applicable.

Acknowledgments: We thank Jin-Qiu Zhou (Chinese Academy of Sciences) and his lab members Zhenfang Wu, Jia-Cheng Liu, Chen Cai and Qiong-Di Zhang for strains, plasmids and tetrad dissection assistance.

Conflicts of Interest: The authors declare no conflict of interest.

\section{References}

1. Shay, J.W. Role of Telomeres and Telomerase in Aging and Cancer. Cancer Discov. 2016, 6, 584-593. [CrossRef] [PubMed]

2. Opresko, P.L.; Shay, J.W. Telomere-associated aging disorders. Ageing Res. Rev. 2017, 33, 52-66. [CrossRef] [PubMed]

3. Martínez, P.; Blasco, M.A. Telomere-driven diseases and telomere-targeting therapies. J. Cell Biol. 2017, 216, 875-887. [CrossRef]

4. López-Otín, C.; Blasco, M.A.; Partridge, L.; Serrano, M.; Kroemer, G. The Hallmarks of Aging. Cell 2013, $153,1194-1217$. [CrossRef] [PubMed]

5. Falandry, C.; Bonnefoy, M.; Freyer, G.; Gilson, E. Biology of Cancer and Aging: A Complex Association With Cellular Senescence. J. Clin. Oncol. 2014, 32, 2604-2610. [CrossRef] [PubMed]

6. Hass, E.P.; Zappulla, D.C. The Ku subunit of telomerase binds Sir4 to recruit telomerase to lengthen telomeres in S. cerevisiae. eLife 2015, 4, e07750. [CrossRef] [PubMed]

7. Chen, H.; Xue, J.; Churikov, D.; Hass, E.P.; Shi, S.; Lemon, L.D.; Luciano, P.; Bertuch, A.A.; Zappulla, D.C.; Géli, V.; et al. Structural Insights into Yeast Telomerase Recruitment to Telomeres. Cell 2018, 172, 331. [CrossRef] [PubMed]

8. Kupiec, M. Biology of telomeres: Lessons from budding yeast. FEMS Microbiol. Rev. 2014, 38, 144-171. [CrossRef] [PubMed]

9. Wellinger, R.J.; Zakian, V.A. Everything You Ever Wanted to Know About Saccharomyces cerevisiae Telomeres: Beginning to End. Genetics 2012, 191, 1073-1105. [CrossRef] 
10. Lundblad, V.; Szostak, J.W. A mutant with a defect in telomere elongation leads to senescence in yeast. Cell 1989, 57, 633-643. [CrossRef]

11. Lendvay, T.S.; Morris, D.K.; Sah, J.; Balasubramanian, B.; Lundblad, V. Senescence Mutants of Saccharomyces cerevisiae With a Defect in Telomere Replication Identify Three Additional EST Genes. Genetics 1996, 144, 1399-1412. [CrossRef] [PubMed]

12. Singer, M.S.; Gottschling, D.E. TLC1: Template RNA component of Saccharomyces cerevisiae telomerase. Science 1994, 266, 404-409. [CrossRef]

13. Lemieux, B.; Laterreur, N.; Perederina, A.; Noël, J.F.; Dubois, M.L.; Krasilnikov, A.S.; Wellinger, R.J. Active Yeast Telomerase Shares Subunits with Ribonucleoproteins RNase P and RNase MRP. Cell 2016, 165, 1171-1181. [CrossRef] [PubMed]

14. Stellwagen, A.E.; Haimberger, Z.W.; Veatch, J.R.; Gottschling, D.E. Ku interacts with telomerase RNA to promote telomere addition at native and broken chromosome ends. Genes Dev. 2003, 17, 2384-2395. [CrossRef] [PubMed]

15. Peterson, S.E.; Stellwagen, A.E.; Diede, S.J.; Singer, M.S.; Haimberger, Z.W.; Johnson, C.O.; Tzoneva, M.; Gottschling, D.E. The function of a stem-loop in telomerase RNA is linked to the DNA repair protein Ku. Nat. Genet. 2001, 27, 64-67. [CrossRef] [PubMed]

16. Bertuch, A.A.; Lundblad, V. EXO1 Contributes to Telomere Maintenance in Both Telomerase-Proficient and Telomerase-Deficient Saccharomyces cerevisiae. Genetics 2004, 166, 1651-1659. [CrossRef]

17. Mimitou, E.P.; Symington, L.S. Ku prevents Exo1 and Sgs1-dependent resection of DNA ends in the absence of a functional MRX complex or Sae2. EMBO J. 2010, 29, 3358-3369. [CrossRef]

18. Liu, J.; Wang, L.; Wang, Z.; Liu, J.-P. Roles of Telomere Biology in Cell Senescence, Replicative and Chronological Ageing. Cells 2019, 8, 54. [CrossRef]

19. Nugent, C.I.; Hughes, T.R.; Lue, N.F.; Lundblad, V. Cdc13p: A Single-Strand Telomeric DNA-Binding Protein with a Dual Role in Yeast Telomere Maintenance. Science 1996, 274, 249. [CrossRef]

20. Lundblad, V.; Blackburn, E.H. An alternative pathway for yeast telomere maintenance rescues est1- senescence. Cell 1993, 73, 347-360. [CrossRef]

21. Nugent, C.I.; Bosco, G.; Ross, L.O.; Evans, S.K.; Salinger, A.P.; Moore, J.K.; Haber, J.E.; Lundblad, V. Telomere maintenance is dependent on activities required for end repair of double-strand breaks. Curr. Biol. 1998, 8, 657-662. [CrossRef]

22. Maringele, L.; Lydall, D. EXO1 Plays a Role in Generating Type I and Type II Survivors in Budding Yeast. Genetics 2004, 166, 1641-1649. [CrossRef] [PubMed]

23. Le, S.; Moore, J.K.; Haber, J.E.; Greider, C.W. RAD50 and RAD51 Define Two Pathways That Collaborate to Maintain Telomeres in the Absence of Telomerase. Genetics 1999, 152, 143-152. [PubMed]

24. Signon, L.; Malkova, A.; Naylor, M.L.; Klein, H.; Haber, J.E. Genetic Requirements for RAD51- and RAD54-Independent Break-Induced Replication Repair of a Chromosomal Double-Strand Break. Mol. Cell. Biol. 2001, 21, 2048. [CrossRef] [PubMed]

25. Lydeard, J.R.; Jain, S.; Yamaguchi, M.; Haber, J.E. Break-induced replication and telomerase-independent telomere maintenance require Pol32. Nature 2007, 448, 820-823. [CrossRef] [PubMed]

26. Churikov, D.; Charifi, F.; Simon, M.-N.; Géli, V. Rad59-Facilitated Acquisition of $Y^{\prime}$ elements by Short Telomeres Delays the Onset of Senescence. PLoS Genet. 2014, 10, e1004736. [CrossRef] [PubMed]

27. Laud, P.R.; Multani, A.S.; Bailey, S.M.; Wu, L.; Ma, J.; Kingsley, C.; Lebel, M.; Pathak, S.; DePinho, R.A.; Chang, S. Elevated telomeretelomere recombination in WRN-deficient, telomere dysfunctional cells promotes escape from senescence and engagement of the ALT pathway. Genes Dev. 2005, 19, 2560-2570. [CrossRef]

28. McEachern, M.J.; Iyer, S. Short Telomeres in Yeast Are Highly Recombinogenic. Mol. Cell 2001, 7, 695-704. [CrossRef]

29. Morrish, T.A.; Greider, C.W. Short Telomeres Initiate Telomere Recombination in Primary and Tumor Cells. PLoS Genet. 2009, 5, e1000357. [CrossRef] [PubMed]

30. Luo, K.; Vega-Palas, M.A.; Grunstein, M. Rap1-Sir4 binding independent of other Sir, yKu, or histone interactions initiates the assembly of telomeric heterochromatin in yeast. Genes Dev. 2002, 16, 1528-1539. [CrossRef]

31. Aparicio, O.M.; Billington, B.L.; Gottschling, D.E. Modifiers of position effect are shared between telomeric and silent mating-type loci in S. cerevisiae. Cell 1991, 66, 1279-1287. [CrossRef]

32. Kueng, S.; Oppikofer, M.; Gasser, S.M. SIR Proteins and the Assembly of Silent Chromatin in Budding Yeast. Annu. Rev. Genet. 2013, 47, 275-306. [CrossRef] [PubMed]

33. Gallardo, F.; Laterreur, N.; Cusanelli, E.; Ouenzar, F.; Querido, E.; Wellinger, R.J.; Chartrand, P. Live Cell Imaging of Telomerase RNA Dynamics Reveals Cell Cycle-Dependent Clustering of Telomerase at Elongating Telomeres. Mol. Cell 2011, 44, 819-827. [CrossRef]

34. Wotton, D.; Shore, D. A novel Rap1p-interacting factor, Rif2p, cooperates with Rif1p to regulate telomere length in Saccharomyces cerevisiae. Genes Dev. 1997, 11, 748-760. [CrossRef] [PubMed]

35. Pfingsten, J.S.; Goodrich, K.J.; Taabazuing, C.; Ouenzar, F.; Chartrand, P.; Cech, T.R. Mutually Exclusive Binding of Telomerase RNA and DNA by Ku Alters Telomerase Recruitment Model. Cell 2012, 148, 922-932. [CrossRef]

36. Longtine, M.S.; Mckenzie III, A.; Demarini, D.J.; Shah, N.G.; Wach, A.; Brachat, A.; Philippsen, P.; Pringle, J. RAdditional modules for versatile and economical PCR-based gene deletion and modification in Saccharomyces cerevisiae. Yeast 1998, 14, 953-961. [CrossRef]

37. Sikorski, R.S.; Hieter, P. A system of shuttle vectors and yeast host strains designed for efficient manipulation of DNA in Saccharomyces cerevisiae. Genetics 1989, 122, 19-27. [CrossRef] [PubMed] 
38. Liu, J.; He, M.H.; Peng, J.; Duan, Y.M.; Lu, Y.S.; Wu, Z.; Gong, T.; Li, H.T.; Zhou, J.Q. Tethering telomerase to telomeres increases genome instability and promotes chronological aging in yeast. Aging 2016, 8, 2827-2840. [CrossRef] [PubMed]

39. Liu, J.; Liu, J.-P. A method for efficient quantitative analysis of genomic subtelomere $\mathrm{Y}^{\prime}$ element abundance in yeasts. Yeast 2020, 37, 373-388. [CrossRef] [PubMed]

40. Rodrigues, J.; Lydall, D. Paf1 and Ctr9, core components of the PAF1 complex, maintain low levels of telomeric repeat containing RNA. Nucleic Acids Res. 2017, 46, 621-634. [CrossRef] [PubMed]

41. Bupp, J.M.; Martin, A.E.; Stensrud, E.S.; Jaspersen, S.L. Telomere anchoring at the nuclear periphery requires the budding yeast Sad1-UNC-84 domain protein Mps3. J. Cell Biol. 2007, 179, 845-854. [CrossRef] [PubMed]

42. Ferreira, H.C.; Luke, B.; Schober, H.; Kalck, V.; Lingner, J.; Gasser, S.M. The PIAS homologue Siz2 regulates perinuclear telomere position and telomerase activity in budding yeast. Nat. Cell Biol. 2011, 13, 867. [CrossRef] [PubMed]

43. Takata, H.; Tanaka, Y.; Matsuura, A. Late S Phase-Specific Recruitment of Mre11 Complex Triggers Hierarchical Assembly of Telomere Replication Proteins in Saccharomyces cerevisiae. Mol. Cell 2005, 17, 573-583. [CrossRef] [PubMed]

44. de Bruin, D.; Zaman, Z.; Liberatore, R.A.; Ptashne, M. Telomere looping permits gene activation by a downstream UAS in yeast. Nature 2001, 409, 109. [CrossRef] [PubMed]

45. Poschke, H.; Dees, M.; Chang, M.; Amberkar, S.; Kaderali, L.; Rothstein, R.; Luke, B. Rif2 Promotes a Telomere Fold-Back Structure through Rpd3L Recruitment in Budding Yeast. PLoS Genet. 2012, 8, e1002960. [CrossRef] [PubMed] 